\title{
Population Dynamics of Sugarcane Plassey Borer Chilo tumidicostalis Hmpson (Lepidoptera: Pyralidae)
}

\author{
R.K. Nath $^{1 *}$ and D.K. Saikia ${ }^{2}$ \\ ${ }^{1}$ Department of Entomology, Krishi Vigyan Kendra, Assam Agricultural University, \\ Tinsukia-786 125, India \\ ${ }^{2}$ Department of Entomology, Assam Agricultural University, Jorhat-785 013, India \\ *Corresponding author
}

\section{A B S T R A C T}

\section{Keywords}

Plassey borer,

Primary infestation,

Secondary

infestation, Spindle

etc.

\section{Article Info}

Accepted:

12 February 2018

Available Online:

10 March 2018
Investigation on the population dynamics of sugarcane plassey borer, Chilo tumidicostalis Hmpsn (Lepidoptera: Pyralidae) was carried out in laboratory and fields during 2014-15 and 2015-16. The cane damaged by the insect started in case of primary infestation from first fortnight of April 2014 with a peak (10.36\%) in the first fortnight of July. In the case of secondary infestation, per cent incidence of the cane was observed lately in the second fortnight of June with a highest peak (19.53\%) in the first half of November. The larval population of insect in case of primary and secondary infestation was observed in second fortnight of April and August for both the year, 2014-15 and 2015-16 respectively. Cotesia flavipes was an important potential parasitoid parasitizing 40.07 per cent in second fortnight of September and 39.04 per cent in second fortnight of September for the year 2014-15 and 2015-16, respectively. In the field maximum and minimum temperature, morning and evening relative humidity, total rainfall had positive correlation with the pest population while number of rainy days showed negative influence on the population buildup of the insect.

\section{Introduction}

Sugarcane is one of the important cash crops grown in all the tropical and sub-tropical countries of the world. In Assam, sugarcane is the important commercial crop grown in all the districts next to tea and jute with an area and production of 0.30 lakh ha and 10.76 lakh metric tons tons, respectively (Anon., 2014). The insect pest problem is one of the important limiting factors in the production of sugarcane crop. Among the various insect pests, early shoot borer, Chilo infuscatellus
Snellen, top borer, Scirpophaga excerptalis Walker and Plassey borer, Chilo tumidicostalis Hampson are the three major borer species that attacked sugarcane in Assam along with red rot disease (Patil et al., 2006). The plassey broer, $C$. tumidicostalis caused 8.2 to 12.6 per cent loss in cane yield and 1.25 to 7.85 per cent loss in sucrose output in endemic areas (Butani, 1961). Population dynamics is the study of key factors which contribute to natural mortality under field condition and it involves not only the investigation of the causation of changes 
of the total number in a given time and space, but also of the mechanism of natural control (Atwal and Bains, 1974). In view of the above factors, the present study is undertaken to investigate the population dynamics of $C$. tumidicostalis.

\section{Materials and Methods}

The present investigation on population dynamics of sugarcane plassey borer $C$. tumidicostalis Hampson (Lepidoptera: Pyralidae) were carried out during 2014-15 and 2015-16, respectively. The estimation of the absolute population and seasonal incidence of $C$. tumidicostalis were made in three sugarcane fields situated at Margherita, Kakapather and Gellapukhuri area of Tinsukia district, Assam.

Field population of $C$. tumidicostalis and its natural enemies

The absolute population of larva of $C$. tumidicostalis and its natural enemies and the incidence of damaged cane was recorded in the selected fields. Observations were made at fortnightly interval starting from first fortnight of February, 2014 till harvest of the crop. Population count of the insect was made in randomly selected 30 quadrates in a given field during in each sampling occasion of the farmer's field at Margherita, Kakapather and Gellapukhuri area of Tinsukia district and all the plants collected from the sample was examined for the presence of dry crown, borer holes, frass, and damaged internodes caused by the insect. The total population in all the 30 quadrates was used to estimate the absolute population of larvae as well as its natural enemy for a given sampling date. For determining the extent of parasitization, the borer larvae collected from the field at each observation was brought to the laboratory and reared on cut pieces of internodes, measuring $6 "$ in length. The presence of cocoon of the parasitoid near the dead larvae of the host insect collected from the field was considered as the dead of the larvae due to parasitization. The percentage of parasitization was calculated on the basis of total population of larvae and parasitized larvae in each observation.

\section{Sampling technique}

The population count of Chilo tumidicostalis was made in $1 \mathrm{~m} \times 1 \mathrm{~m}$ quadrate and thirty randomly selected quadrates in a given field were examined in each sampling occasion. The infested plants were cut open longitudinally to record the population of larvae and pupae and also that of the parasitized larvae and pupae. The observed total population in all the thirty quadrates was used to estimate the absolute population of larvae and pupae of the pest as well as its natural enemies for a given sampling date.

\section{Parasitism of eggs}

To determine the extent of parasitism by the egg parasitoids, five egg clusters was collected from each of the three fields in each generation and kept in small glass specimen tubes separately for hatching and the number of hatching larvae as well as the number of parasitoids emerged was counted. On completion of hatching, each egg mass examined separately for recording the parasitoids. The percentage of egg parasitism was determined on the basis of the total number of eggs observed.

\section{Results and Discussion}

Incidence of cane damaged by $C$. tumidicostalis in different months during 2014-15

The data on the incidence of cane damaged (average of 3 fields i.e. Margherita, 
Kakapather and Gellapukhuri) at primary and secondary infestation of the insect during 2014-15 and 2015-16 are presented in Table 1. The observed data indicated that the cane damaged by the insect started in case of primary infestation from first fortnight of April 2014 with 0.45 per cent. After wards, damaged to the cane by the insect showed a steady increase, reaching a peak in the first fortnight of July (10.36\%). However, it was observed that in the subsequent months i.e. from second fortnight of July, 2014, there was a decreasing trend in the percentage of primary damaged cane by the insect. There was no any primary damage symptoms caused by $C$. tumidicostalis from second fortnight of October till harvesting of the crop i.e. up to March, 2015.

In case of secondary infestation, per cent incidence of the cane was observed lately in the second fortnight of June $(0.68 \%)$ and was observed to be increased gradually up to first half of November, 2014 with a highest peak of 19.53 per cent. After that, a decreasing trend of infestation was observed in the secondary infestation from second fortnight of November, 2014. During 2015-16 also, in case of primary infestation, a similar trend of per cent infestation was observed, indicating cane damaged by $C$. tumidicostalis from first fortnight of April 2015 with 0.67 per cent. The insect showed a steady increase and caused maximum damage to the cane in the second fortnight of June (11.55\%). But the infestation of the insect showed a decreasing trend of primary infestation from first fortnight of July to October, 2015 ranging from 10.77 to 0.43 per cent cane damage. Similarly, the per cent incidence of secondary infestation of the cane was observed lately, in the first fortnight of July $(0.76 \%)$ whereas maximum damaged cane was observed with a highest infestation of 21.78 per cent during first fortnight of November, 2015. But, a decreasing trend of secondary infestation was observed from second fortnight of November, 2015 to till harvest of the crop.

The per cent infestation level of decreasing trend of the C. tumidicostalis from October to till harvesting of the crop was due to the fact that the larvae during this period underwent hibernation and did not cause any new damage in case of both the infestation (primary and secondary) during both the years. However, Khanna et al., (1957) reported the appearance of the pest in the early March which was slightly early compared to present study. In the subsequent months i.e. from second fortnight of December to March for both the years, the per cent infestation of total damaged cane by the insect was observed to be decreased gradually and which might be due to fact that some canes got perished completely due to some physiological factors. It was observed that the secondary damaged to the canes found to be started on second fortnight of June for both the cropping seasons. This might be due to the fact that larvae which remained in congregation in primary infested canes migrated to other cane only after completion of third instar leading to secondary damage. Further, increase in the infested cane in both type of damage was not observed in the field. This indicated that the larva stop feeding and there was no further new incidence of damaged cane. These findings were in conformity with Bhuyan, (1999) who reported that the pest incidence was first noticed in the field during the second fortnight of February, 1998. Rajmedhi (1992) also reported that the pest incidence was first noticed in the field during the first fortnight of April on January planted crop. The peak period activity of the pest was from July to November with three minor peaks during August, October and November. The pest underwent hibernation in larval stage during winter from the later part of December till January. The population of insect was comprised of only fully matured larval stage 
during December, 2014 and January, 2015 and it was indicated that the insect underwent hibernation during severe cold prevailing during that periods. By the end of March, all the larvae were found to be pupated. The larval diapauses in $C$. tumidicostalis during December to January was also reported by Khanna et al., (1957) from Bihar, Gupat and Avasthy (1959) from Lucknow, Uttar Pradesh and Rajmedhi (1992) from Assam and which supported the present investigations.

\section{Absolute population of $C$. tumidicostalis (larvae) in different months}

The data on the mean absolute population of C. tumidicostalis (larvae $/ \mathrm{m}^{2}$ ) for the year 2014-15 and 2015-16 (average of 3 fields) are presented in Table 2.

The data indicated that the population of insect (comprising only larvae) in case of primary infestation started to build up from first fortnight of April, 2014. A steady increase in the population of larvae in subsequent months was observed reaching with a peak of $17.37 / \mathrm{m}^{2}$ in the second fortnight of August during 2014-15 and first fortnight of August with 15.20 larvae $/ \mathrm{m}^{2}$ during 2015-16, respectively and it was near about 240 days after the first appearance of the insect. In case of secondary infestation, it was observed from first fortnight of August, 201415 and maximum number of larval population was observed with a peak of $5.73 / \mathrm{m}^{2}$ and $5.83 / \mathrm{m}^{2}$ in first fortnight of November, for the year 2014-15 and 2015-16, respectively. After wards, the population of larvae showed declining trend from November, 2014 to March, 2015. It was observed that the decline in the population of larvae from November to March was related to high parasitization of the larvae by a hymenopteran parasitoid Cotesia flavipes which was found to be active from July onward for both the season and resulted in maximum parasitization (40.07 and 39.04\% during 2014-15 and 2015-16, respectively) of the insect during September for both the year 2014-15 and 2015-16. It was observed during the investigation that the diapausing larvae started pupation from first fortnight of February onwards for both the investigation periods, 2014-15 and 2015-16, respectively which indicated termination of larval diapause in insect which might be due to steady increasing of temperature from January onwards.

According to Khanna et al., (1957) and Gupta and Avasthy (1959), the insect $C$. tumidicostalis appeared early in March in Bihar and during the middle of February in West Bengal, respectively. However, Bhuyan (1999) also reported that the larval population of the insect was noticed in the field during the second fortnight of February. The larval and pupal population reached a peak in first fortnight of November and thereafter the population showed a gradual decline. Field population showed the presence of only larval stages from December to January indicating diapausing character of the larvae to overcome cold weather. The probable reason for this variation in the appearance of the pest could be attributed to the variations in the physical factors of the environments prevailing in different localities of sugarcane growing areas. The extent of parasitization of $C$. tumidicostalis larvae by $C$. flavipes in different months are presented in Table 3 . The data indicated that parasitization of larvae of C. tumidicostalis was first observed from June, 2014 and 2015 onwards and parasitization trend showed a steady increase reaching a peak of 40.07 per cent and 39.04 per cent in second fortnight of September for both the year 2014-15 2015-16, respectively. It was observed that the parasitoid was active from June to November for both the experimental years. However, no larval parasitoid was noticed after November onwards for both the years of investigation. 
Table.1 Incidence of damaged canes by $C$. tumidicostalis

\begin{tabular}{|c|c|c|c|c|c|c|c|}
\hline \multirow[t]{2}{*}{ Month } & \multirow[t]{2}{*}{ Fortnight } & \multicolumn{3}{|c|}{ 2014-15 } & \multicolumn{3}{|c|}{$2015-16$} \\
\hline & & $\begin{array}{c}\text { Primary } \\
\text { Infestation }(\%)\end{array}$ & $\begin{array}{c}\text { Secondary } \\
\text { Infestation (\%) }\end{array}$ & $\begin{array}{c}\text { Total } \\
\text { Infestation }(\%)\end{array}$ & $\begin{array}{c}\text { Primary } \\
\text { Infestation }(\%)\end{array}$ & $\begin{array}{c}\text { Secondary } \\
\text { Infestation }(\%)\end{array}$ & $\begin{array}{c}\text { Total } \\
\text { Infestation }(\%)\end{array}$ \\
\hline \multirow[t]{2}{*}{ February } & I & 0 & 0 & 0 & 0 & 0 & 0 \\
\hline & II & 0 & 0 & 0 & 0 & 0 & 0 \\
\hline \multirow[t]{2}{*}{ March } & I & 0 & 0 & 0 & 0 & 0 & 0 \\
\hline & II & 0 & 0 & 0 & 0 & 0 & 0 \\
\hline \multirow[t]{2}{*}{ April } & I & 0.45 & 0 & 0.45 & 0.67 & 0 & 0.67 \\
\hline & II & 0.68 & 0 & 0.68 & 0.89 & 0 & 0.89 \\
\hline \multirow[t]{2}{*}{ May } & I & 2.17 & 0 & 2.17 & 3.46 & 0 & 3.46 \\
\hline & II & 4.16 & 0 & 4.16 & 4.13 & 0 & 4.13 \\
\hline \multirow[t]{2}{*}{ June } & I & 8.78 & 0 & 8.78 & 9.86 & 0 & 9.86 \\
\hline & II & 8.97 & 0.68 & 9.65 & 11.55 & 0 & 11.55 \\
\hline \multirow[t]{2}{*}{ July } & I & 10.36 & 5.64 & 16 & 10.77 & 0.76 & 11.53 \\
\hline & II & 5.43 & 14.25 & 19.68 & 4.47 & 10.45 & 14.92 \\
\hline \multirow[t]{2}{*}{ August } & I & 3.23 & 11.73 & 14.96 & 4.23 & 10.11 & 14.34 \\
\hline & II & 3.12 & 10.41 & 13.53 & 3.64 & 9.78 & 13.42 \\
\hline \multirow[t]{2}{*}{ September } & I & 2.75 & 9.25 & 12 & 3.09 & 8.74 & 11.83 \\
\hline & II & 0.65 & 8.74 & 9.39 & 2.55 & 8.98 & 11.53 \\
\hline \multirow[t]{2}{*}{ October } & I & 0.48 & 8.46 & 8.94 & 1.08 & 9.14 & 10.22 \\
\hline & II & 0 & 9.05 & 9.05 & 0.43 & 9.89 & 10.32 \\
\hline \multirow[t]{2}{*}{ November } & I & 0 & 19.53 & 19.53 & 0 & 21.78 & 21.78 \\
\hline & II & 0 & 1.57 & 1.57 & 0 & 1.68 & 1.68 \\
\hline \multirow[t]{2}{*}{ December } & I & 0 & 0.92 & 0.92 & 0 & 0.93 & 0.93 \\
\hline & II & 0 & 0.79 & 0.79 & 0 & 0.75 & 0.75 \\
\hline \multirow[t]{2}{*}{ January } & I & 0 & 0.32 & 0.32 & 0 & 0.42 & 0.42 \\
\hline & II & 0 & 0 & 0 & 0 & 0 & 0 \\
\hline \multirow[t]{2}{*}{ February } & I & 0 & 0 & 0 & 0 & 0 & 0 \\
\hline & II & 0 & 0 & 0 & 0 & 0 & 0 \\
\hline \multirow[t]{2}{*}{ March } & I & 0 & 0 & 0 & 0 & 0 & 0 \\
\hline & II & 0 & 0 & 0 & 0 & 0 & 0 \\
\hline
\end{tabular}

*Average of 3 field. 
Table.2 Absolute population of $C$. tumidicostalis (larva) in different months

\begin{tabular}{|c|c|c|c|c|c|}
\hline \multirow[t]{3}{*}{ Month } & \multirow[t]{3}{*}{ Fortnight } & \multicolumn{2}{|c|}{$2014-15$} & \multicolumn{2}{|c|}{$2015-16$} \\
\hline & & $\begin{array}{c}\text { Primary Infestation } \\
\text { (Dry crown) }\end{array}$ & $\begin{array}{l}\text { Secondary Infestation } \\
\text { (Damaged internode) }\end{array}$ & $\begin{array}{c}\text { Primary Infestation } \\
\text { (Dry crown) }\end{array}$ & $\begin{array}{l}\text { Secondary Infestation } \\
\text { (Damaged internode) }\end{array}$ \\
\hline & & No. of larvae $/ \mathrm{m}^{2}$ & No. of larvae $/ \mathrm{m}^{2}$ & No. of larvae/m² & No. of larvae $/ \mathrm{m}^{2}$ \\
\hline \multirow[t]{2}{*}{ February } & I & 0 & 0 & 0 & 0 \\
\hline & II & 0 & 0 & 0 & 0 \\
\hline \multirow[t]{2}{*}{ March } & I & 0 & 0 & 0 & 0 \\
\hline & II & 0 & 0 & 0 & 0 \\
\hline \multirow[t]{2}{*}{ April } & I & 2.97 & 0 & 3.23 & 0 \\
\hline & II & 3.20 & 0 & 3.57 & 0 \\
\hline \multirow[t]{2}{*}{ May } & $\mathrm{I}$ & 3.53 & 0 & 4.13 & 0 \\
\hline & II & 8.17 & 0 & 6.60 & 0 \\
\hline \multirow[t]{2}{*}{ June } & I & 8.40 & 0 & 7.80 & 0 \\
\hline & II & 8.97 & 0 & 8.57 & 0 \\
\hline \multirow[t]{2}{*}{ July } & I & 12.13 & 0 & 8.97 & 0 \\
\hline & II & 12.73 & 0 & 12.60 & 0 \\
\hline \multirow[t]{2}{*}{ August } & I & 16.23 & 4.93 & 15.20 & 4.60 \\
\hline & II & 17.37 & 5.07 & 7.20 & 4.87 \\
\hline \multirow[t]{2}{*}{ September } & I & 7.27 & 5.17 & 5.93 & 5.30 \\
\hline & II & 5.93 & 5.33 & 5.50 & 5.40 \\
\hline \multirow[t]{2}{*}{ October } & I & 4.23 & 5.50 & 3.97 & 5.60 \\
\hline & II & 0 & 5.63 & 0 & 5.70 \\
\hline \multirow[t]{2}{*}{ November } & I & 0 & 5.73 & 0 & 5.83 \\
\hline & II & 0 & 2.73 & 0 & 2.30 \\
\hline \multirow[t]{2}{*}{ December } & I & 0 & 0 & 0 & 0 \\
\hline & II & 0 & 0 & 0 & 0 \\
\hline \multirow[t]{2}{*}{ January } & I & 0 & 0 & 0 & 0 \\
\hline & II & 0 & 0 & 0 & 0 \\
\hline \multirow[t]{2}{*}{ February } & I & 0 & 0 & 0 & 0 \\
\hline & II & 0 & 0 & 0 & 0 \\
\hline \multirow[t]{2}{*}{ March } & I & 0 & 0 & 0 & 0 \\
\hline & II & 0 & 0 & 0 & 0 \\
\hline
\end{tabular}


Table.3 Extent of parasitization of $C$. tumidicostalis larvae by Cotesia flavipes in different months

\begin{tabular}{|c|c|c|c|c|c|c|c|}
\hline \multirow[t]{2}{*}{ Month } & \multirow[t]{2}{*}{ Fortnight } & \multicolumn{3}{|c|}{ 2014-15 } & \multicolumn{3}{|c|}{ 2015-16 } \\
\hline & & $\begin{array}{c}\text { No. of larvae/ } \\
\mathbf{m}^{2}\end{array}$ & $\begin{array}{l}\text { No. of } \\
\text { parasitized } \\
\text { larvae } / \mathbf{m}^{2}\end{array}$ & $\begin{array}{c}\text { Extent of } \\
\text { parasitization } \\
(\%)\end{array}$ & $\begin{array}{c}\text { No. of larvae/ } \\
\mathbf{m}^{2}\end{array}$ & $\begin{array}{c}\text { No. of } \\
\text { parasitized } \\
\text { larvae } / \mathbf{m}^{2}\end{array}$ & $\begin{array}{c}\text { Extent of } \\
\text { parasitization } \\
(\%)\end{array}$ \\
\hline \multirow[t]{2}{*}{ February } & I & 0.00 & 0.00 & 0 & 0 & 0 & 0 \\
\hline & II & 0.00 & 0.00 & 0 & 0 & 0 & 0 \\
\hline \multirow[t]{2}{*}{ March } & I & 0.00 & 0.00 & 0 & 0 & 0 & 0 \\
\hline & II & 0.00 & 0.00 & 0 & 0 & 0 & 0 \\
\hline \multirow[t]{2}{*}{ April } & I & 0.00 & 0.00 & 0 & 0 & 0 & 0 \\
\hline & II & 3.63 & 0.00 & 0 & 78 & 0 & 0 \\
\hline \multirow[t]{2}{*}{ May } & I & 8.47 & 0.00 & 0 & 112 & 0 & 0 \\
\hline & II & 8.97 & 0.00 & 0 & 326 & 0 & 0 \\
\hline \multirow[t]{2}{*}{ June } & I & 8.07 & 0.00 & 0 & 421 & 0 & 0 \\
\hline & II & 8.97 & 0.00 & 0 & 416 & 0 & 0 \\
\hline \multirow[t]{2}{*}{ July } & I & 12.23 & 1.53 & 12.53 & 540 & 57 & 10.55 \\
\hline & II & 12.97 & 1.93 & 14.91 & 562 & 77 & 13.70 \\
\hline \multirow[t]{2}{*}{ August } & I & 18.80 & 7.10 & 20.74 & 256 & 56 & 21.87 \\
\hline & II & 17.37 & 3.10 & 17.85 & 287 & 46 & 16.02 \\
\hline \multirow[t]{2}{*}{ September } & I & 19.93 & 6.30 & 31.61 & 203 & 56 & 27.58 \\
\hline & II & 18.13 & 7.27 & 40.07 & 105 & 41 & 39.04 \\
\hline \multirow[t]{2}{*}{ October } & $\mathrm{I}$ & 17.40 & 3.47 & 19.92 & 109 & 22 & 20.13 \\
\hline & II & 22.60 & 6.57 & 29.05 & 198 & 37 & 18.68 \\
\hline \multirow[t]{2}{*}{ November } & I & 17.77 & 4.03 & 22.70 & 112 & 26 & 23.21 \\
\hline & II & 16.93 & 0.60 & 3.54 & 154 & 32 & 20.78 \\
\hline \multirow[t]{2}{*}{ December } & I & 16.60 & 0.00 & 0 & 206 & 0 & 0 \\
\hline & II & 15.87 & 0.00 & 0 & 245 & 0 & 0 \\
\hline \multirow[t]{2}{*}{ January } & I & 12.90 & 0.00 & 0 & 112 & 0 & 0 \\
\hline & II & 12.30 & 0.00 & 0 & 97 & 0 & 0 \\
\hline \multirow[t]{2}{*}{ February } & I & 8.17 & 0.00 & 0 & 85 & 0 & 0 \\
\hline & II & 7.13 & 0.00 & 0 & 74 & 0 & 0 \\
\hline \multirow[t]{2}{*}{ March } & I & 2.23 & 0.00 & 0 & 70 & 0 & 0 \\
\hline & II & 1.87 & 0.00 & 0 & 67 & 0 & 0 \\
\hline
\end{tabular}


Table.4 Correlation between larval population of $C$. tumidicostalis and meteorological factor during 2015-16

\begin{tabular}{l|l|l|}
\hline \multicolumn{1}{|c|}{ Factor correlated larval population with mean } & Correlation coefficient & Regression equation \\
\hline $\begin{array}{l}\text { Mean } \\
\text { maximum temperature }\left({ }^{\circ} \mathrm{C}\right)\end{array}$ & $0.605^{* * *}$ & $\mathrm{y}=41.09 \mathrm{x}-706.03$ \\
\hline $\begin{array}{l}\text { Mean larval population with mean } \\
\text { minimum temperature }\left({ }^{\circ} \mathrm{C}\right)\end{array}$ & $0.528^{* *}$ & $\mathrm{y}=27.53 \mathrm{x}-0.017$ \\
\hline $\begin{array}{l}\text { Mean larval population with mean } \\
\text { maximum relative humidity }(\%)\end{array}$ & $0.405^{*}$ & $\mathrm{y}=27.08 \mathrm{x}-2108.76$ \\
\hline $\begin{array}{l}\text { Mean larval population with mean } \\
\text { minimum relative humidity }(\%)\end{array}$ & $0.480^{* *}$ & $\mathrm{y}=9.43 \mathrm{x}-159.23$ \\
\hline $\begin{array}{l}\text { Mean larval population with mean total } \\
\text { rainfall (mm) }\end{array}$ & $0.219^{\mathrm{NS}}$ & $\mathrm{y}=0.32 \mathrm{x}+409.89$ \\
\hline $\begin{array}{l}\text { Mean larval population with mean number } \\
\text { of rainy days } \\
* * \text { Significant at } \mathrm{P}=0.05 \text { and } 0.01\end{array}$ & $-0.093^{\mathrm{NS}}$ & $\mathrm{y}=483.6-94.28 \mathrm{x}$ \\
$*$ Significant at $\mathrm{P}=0.05$ \\
NS = Non significant
\end{tabular}

It was obvious that an average absolute population of larval parasitoid was slightly higher in second fortnight of November when the larval population was also higher at that period. Therefore, the attainment of peak population of $C$. flavipes showed remarkable synchrony with that of host population. Hence, the present investigation indicated that the parasitoid population fluctuated more or less in a density dependent manner.

The parasitoid, $C$. flavipes was reported for a very high larval mortality of $C$. tumidicostalis by Khanna et al., (1957) and Butani (1961) during October and November in Bihar. Gupta and Avasthy (1959) also reported 1635 per cent larval mortality of $C$. flavipes during July to August from Luchnow. In Assam, Rajmedhi (1992) reported the activity of this parasitoid from July to November with 26-72 per cent larval mortality and Bhuyan (1999) reported the activity of this parasitoid from July to November parasitizing 12 to 40.5 per cent larvae of $C$. tumidicostalis. Further, some mortality of the larvae was also observed due to unidentified predatory earwig and hymenopteran braconid parasitoid which was also found within the damaged primary and secondary infested canes throughout the cropping seasons.

Influence of weather parameters on cane damage and population of plassey borer during the year 2015-16

The larval population of the insect per 30 quadrate in each sampling date was correlated with weather parameters and the coefficient of correlation is presented in Table 4. The data indicated that amongst the meteorological factors affecting the population of the insect, the maximum temperature was the most dominant factor which showed positive and significant correlation $(\mathrm{r}=0.605)$ for larval population. This was followed by minimum temperature which showed next highest and conspicuous association with significant positive correlation $(\mathrm{r}=0.528)$.

It was further observed that correlation coefficient for maximum and minimum 
relative humidity was also positive and was highly significant for maximum $(\mathrm{r}=0.405)$ and minimum ( $\mathrm{r}=0.480)$ relative humidity. The total rainfall also showed positive relationship $(r=0.219)$ with the insect population but it was found to be non-significant. However, the only meteorological factor which showed direct negative influence on the insect population was number of rainy days $(\mathrm{r}=$ 0.093). In case of regression equation analysis, the population of $C$. tumidicostalis larvae on various meteorological factors showed a positive linear regression on maximum and minimum temperature, maximum and minimum relative humidity and total rainfall, but the regression was negative on number of rainy days.

These findings were in conformity with the findings of Bhuyan (1999) who reported that the maximum and minimum temperature, morning and evening relative humidity and total rainfall had positive correlation with the pest population while the number of rainy days showed negative influence on the population builds up of the insects.

\section{References}

Anonymous 2014. Economic Survey of Assam. Directorate of Economics and
Statistics, Assam Planning and Development Department, Government of Assam. pp 71.

Atwal, A.S. and Bains S.S. 1974. Applied Animal Ecology. Kalyani Publ., Ludhiana, pp. 245.

Bhuyan, U. 1999. Population dynamics of sugarcane plassey borer, Chilo tumidicostalis (Crambidae: Lepidoptera) and its rate of increase on some sugarcane cultivars. M. Sc. Thesis, Assam Agril. Univ., Jorhat.

Butani, D.K. 1961. Insect pest of sugarcane in Bihar. Indian Sugar 11: 649-54.

Gupta, B.D. and Avasthy, P.N. 1959. Biology and control of stem borer. Chilo tumidicostalis Hmpsn. Proc. Int. Soc. Sug. Cane Technol. 10: 886-901.

Khanna, K.L.; Nigam, L.N. and Puri, V.D. 1957. Chilo tumidicostalis Hmpsn, serious stem borer pests of sugarcane in Bihar. Proc. Indian Acad. Sci. (B). 46:75-95.

Patil, P.D.; Kalaimani, T. and Borkar, S.G. (2006) Prevalence and distribution of sugarcane red rot disease in Tamil Nadu. Ann. Pl. Protec. Sci. 14: 515-516.

Rajmedhi, J. 1992. Biology of sugarcane plassey borer $C$. tumidicostalis Hmpsn (Pyralidae: Lepidoptera). M.Sc. Thesis, Assam Agril. Univ., Jorhat.

\section{How to cite this article:}

Nath, R.K. and Saikia, D.K. 2018. Population Dynamics of Sugarcane Plassey Borer Chilo tumidicostalis Hmpson (Lepidoptera: Pyralidae). Int.J.Curr.Microbiol.App.Sci. 7(03): 13971405. doi: https://doi.org/10.20546/ijcmas.2018.703.167 